\title{
STRATEGI BERPIKIR INTEGRATIF DALAM PEMBELAJARAN MEMBACA LINTAS KURIKULUM DI SEKOLAH DASAR
}

\author{
Miftakhul Huda \\ Email: miftakhul.huda@ums.ac.id
}

\author{
Program Studi Pendidikan Bahasa Indonesia, Fakultas Keguruan dan Ilmu \\ Pendidikan, Universitas Muhammadiyah Surakarta
}

\begin{abstract}
Knowledge and language are relevance. Language is the entrance to knowledge. The competence of language becomes absolutely necessary in the development of knowledge. Language is a reflection of one's mindset. The critical thinking ability of the child will be seen from the use of language. The use of language are reflects a person's schemata. Integrative thinking strategy is a strategy that conditions students in a situation that makes it possible to develop systematic knowledge construction. Integrative's thinking strategies offer the development of students' reasoning. Integrative thinking strategies are very relevant to be used in cross-curriculum learning as these strategies explore and integrate knowledge.
\end{abstract}

keywords: strategy, integrative thinking, reading, cross curriculum

\section{Abstrak}

Pengetahuan dan bahasa memiliki relevansi yang sangat kuat. Bahasa merupakan pintu masuk pengetahuan. Dengan demikian, penguasaan kompetensi berbahasa menjadi mutlak diperlukan dalam pengembangan pengetahuan. Bahasa juga merupakan cerminan pola pikir seseorang. Kemampuan berpikir kritis anak akan terlihat dari penggunaan bahasa. Penggunaan bahasa juga mencerminkan kekayaan skemata seseorang, semakin jaringan skemata seseorang kompleks, semakin baik penggunaan bahasa dalam menjelaskan suatu permasalahan. Strategi berpikir integratif adalah strategi yang mengkondisikan siswa pada suatu keadaan yang memungkinkan untuk mengembangkan konstruksi pengetahuan secara sistematis, sekaligus mengembangkan kemampuan berpikir kritis. Dengan demikian, dalam strategi berpikir integratif menawarkan pengembangan penalaran siswa. Strategi berpikir integratif sangat relevan digunakan dalam pembelajaran lintas kurikulum karena strategi ini mengeksplore dan mengintegrasikan pengetahuan.

kata kunci: strategi, berpikir integratif, membaca, lintas kurikulum

\section{PENDAHULUAN}

Membangun pola pikir anak sangat penting. Anak yang telah terbangun pola pikirnya akan relatif lebih mudah menapaki proses pembelajaran (Chen, Kenneth, and Wang 2017). Membangun pola pikir yang dimaksud adalah membangun penalaran. Kemampuan bernalar akan membangkitkan daya kritis anak. Berpikir kritis akan membawa dampak dalam proses pembelajaram. Anak akan menanyakan dan mencari jawaban atas hal-hal yang belum dipahami dalam pembelajaran. Mulai dari hal ini, siswa akan menjadi pribadi dalam hal mencari ilmu.

Membangun pola pikir dapat dilakukan sejak dini. Anak dapat 26 | Jurnal Kredo Vol. 1 No. 2 April 2018 dikenalkan dengan pertanyaanpertanyaan sederhana untuk merangsang rasa ingin tahu dan logika berpikirnya. Apabila hal tersebut telah menjadi kebiasaan, maka ketika anak itu dewasa akan memetik hasilnya, terutama ketika menghadapi permasalahan. Logika yang baik akan membuat anak tidak mudah terombang-ambing. Anak akan memiliki prinsip dan keyakinan yang kuat di dalam hidupnya.

Pengetahuan dan bahasa memiliki relevansi yang sangat kuat. Bahasa merupakan pintu masuk pengetahuan. Dengan demikian, penguasaan kompetensi berbahasa menjadi mutlak diperlukan dalam pengembangan pengetahuan. Bahasa juga merupakan cerminan pola pikir 
seseorang. Kemampuan berpikir kritis anak akan terlihat dari penggunaan bahasa. Penggunaan bahasa juga mencerminkan kekayaan skemata seseorang, semakin jaringan skemata seseorang kompleks, semakin baik penggunaan bahasa dalam menjelaskan suatu permasalahan.

Dalam pembelajaran, pembangunan pola pikir dapat dilakukan melalui variasi teks bacaan (Heafner, Lipscomb, and Fitchett 2014). Teks-teks yang bervariasi dan utuh akan membantu siswa melatih pola pikir. Misalkan, siswa akan memposisikan pola pikir yang berbeda ketika berhadapan dengan teks narasi dan teks prosedur. Semakin banyak terks yang bervariasi, siswa akan semakin banyak berlatih pola pengembangan teks tersebut. Dengan membaca polapola yang berbeda, secara tidak langsung pola pikir siswa akan berkembang (Martin-beltrán et al. 2017). Selain variasi teks, pengembangan pola pikir juga dapat dilakukan melalui strategi pembelajaran (Plakans and Gebril 2013). Strategi pembelajaran yang membebaskan siswa berpikir dan berkreasi akan membangun pola pikir siswa (Weigle and Parker 2012). Strategi tersebut dapat berada di berbagai mata pelajaran, termasuk pembelajaran membaca.

Di beberapa negara secara umum, kurikulum membaca dalam dekade tertentu dipandang membatasi eksplorasi siswa (Bruce \& Davidson 1996). Pembelajaran membaca sebenarnya memiliki posisi sentral. Apabila kemampuan membaca siswa baik, maka kemampuan yang lain akan tertunjang. Hal ini disebabkan, membaca merupakan pintu masuk untuk mengaktifkan skemata siswa. Melalui skemata, jaringan pengetahuan yang ada di dalam otak siswa akan terhubung sehingga siswa akan baik dalam hal menulis dan berbicara. Lebih dari itu, kemampuan analisis dalam diri siswa akan meningkat. Oleh karena itu, kurikulum yang terbuka dan mampu mengeksplorasi kemampuan siswa dalam pembelajaran membaca sangat penting.

Pembelajaran membaca tidak hanya diperuntukkan bagi mata pelajaran Bahasa Indonesia. Semua mata pelajaran membutuhkan kemampuan membaca. Dengan demikian, pembelajaran membaca dalam konteks ini adalah pembelajaran membaca lintas kurikulum. Teks bacaan dalam ilmu alam berbeda dengan teks bacaan dalam ilmu sosial. Demikian pula dengan teks bacaan bahasa. Oleh karena itu, kemampuan membaca lintas kurikulum sangat diperlukan.

Perbedaan karakteristik teks bacaan dalam mata pelajaran alam, sosial, dan bahasa di antaranya adalah kosa kata (Bintz 2011). Kosa kata dalam setiap mata pelajaran memiliki kekhasan tersendiri. Bahkan, bisa terjadi kata yang sama ketika dalam pelajaran berbeda memiliki interpretasi makna yang tidak sama. Oleh karena itu, diperlukan pembelajaran yang mampu mengakomodasi kosa kata dalam lintas kurikulum (Renshaw 2016). Pembelajaran membaca lintas kurikulum akan menjadi jembatan bagi siswa untuk memahami teks bacaan dari bidang studi yang berbeda (Yuan 2017). Pembelajaran membaca lintas kurikulum menunjukkan bahwa pembelajaran membaca tidak sekadar membunyikan huruf. Lebih dari itu, 
siswa dituntut untuk memahami teks, mereduksi, dan mengabstraksikannya menjadi sebuah pengetahuan yang bisa untuk disampaikan, baik lisan maupun tulis.

Kemampuan membaca siswa dipandang masih rendah. Kemampuan untuk mereduksi informasi dari bahan bacaan kemudian informasi itu diabstraksi menjadi pengetahuan belum dikuasai oleh siswa dengan baik. Akibatnya, pemahaman terhadap materi pelajaran menjadi kurang sempurna. Kondisi ini disebabkan kurangnya latihan membaca. Mata pelajaran tertentu hanya fokus pada penguasaan materi, sedangkan pelajaran Bahasa Indonesia fokus pada materi kebahasaan dan kemampuan berbahasa. Dengan demikian, pembelajaran membaca lintas kurikulum menjadi kurang tersentuh.

Terlebih di sekolah dasar. Ada beberapa urgensitas penelitian membaca lintas kurikulum di sekolah dasar. Usia sekolah dasar merupakan saat penting untuk membentuk pola pikir anak. Pola-pola yang terbentuk pada usia ini sebagian besar akan terbawa ketika anak sudah dewasa. Hal lain yang menjadi urgensitas membaca lintas kurikulum di sekolah dasar adalah pembelajaran tematik. Dalam pembelajaran tematik, sekat antarpelajaran sangat tipis sehingga sangat tepat menggunakan strategi membaca lintas kurikulum. Urgensitas terakhir adalah penelitian tentang membaca lintas kurikulum di sekolah dasar masih sangat sedikit. Padahal, apabila dilihat dari urgensinya, pembelajaran membaca lintas kurikulum termasuk agenda mendesak untuk dilaksanakan di sekolah dasar.
Paparan ini menawarkan strategi berpikir integratif dalam pembelajaran membaca lintas kurikulum untuk meningkatkan reading ability. Berpikir integratif akan membuat siswa berpikir secara global sehingga dapat melihat informasi secara utuh. Informasi yang diperoleh tidak sepotongpotong akan membuat siswa mampu bernalar dengan cara berpikir kritis dan analogis, serta mampu menghubungkan informasi satu dengan informasi yang lain.

\section{PENALARAN PADA SISWA SEKOLAH DASAR}

$\begin{array}{lll}\begin{array}{c}\text { Penalaran } \\ \text { proses }\end{array} & \begin{array}{c}\text { merupakan } \\ \text { berpikir }\end{array} & \text { yatu }\end{array}$ menghubungkan data satu dengan data yang lain (Rapar, 1996: 27-31). Setelah menghubungkan data satu dengan data yang lain, maka akan tercapai kesimpulan. Dalam proses penyimpulan tidak selalu benar. Oleh karena itu, dalam proses penalaran, validitas data sangat penting. Apabila validitas lemah, kesimpulan yang diambil belum tentu benar. Kesimpulan yang diambil dari data yang lemah tidak bisa diterima oleh orang lain sehingga kesimpulan tersebut dinyatakan tidak benar (Djoko, 2011). Proses bernalar dapat dilihat dari dua sisi, yaitu deduktif dan induktif (Ranjabar, 2014: 120121). Penalaran deduktif berangkat dari filsafat positivisme logis, yaitu bermula dari term umum kemudian berkembang kepada kondisi-kondisi khusus, sedangkan penalaran induktif dapat dikatakan sebagai antitesis penalaran deduktif. Penalaran induktif berawal dari kasus-kasus yang bersifat khusus menuju pada sebuah generalisasi. 
Penalaran pada siswa sekolah dasar, dalam bidang eksakta, telah sampai pada menunjukkan bilangan pecahan, benda konkret, dan semi konkret. Dalam bidang bahasa, siswa telah bisa menghubungkan silogisme, contoh: hewan mamalia menyusui, kuda menyesui, berarti kuda hewan mamalia.

Penalaran akan selalu berhubungan dengan perkembangan kognitif. Oleh karena itu, dalam mengkaji perkembangan penalaran, perlu juga dikaji perkembangan kognitif siswa. Tahap-tahap perkembangan kognitif menurut Piaget, di antaranya adalah pada usia 0-2 tahun, anak berada pada tahap sensorimotor. Umur 2-7/8 tahun, anak berada pada tahap praoperasional. Umur 7/8 - 10/11 tahun, anak berada pada tahap operasional konkret. Umur 11/12 18 tahun, anak berada pada tahap operasional formal (Budiningsih, 2004: 35-39).

Pada tahap sensorimotor, anak menunjukkan pertumbuhan motorik dan persepsinya sederhana. Pada tahap ini, kemampuan yang dimiliki oleh anak, di antaranya adalah melihat dirinya sebagai mahluk yang berbeda dengan objek lain, mencari rangsangan melalui sinar/ bunyi, dan melihat objek sebagai sesuatu yang tetap, kemudian ingin mengubah posisi objek tersebut. Pada tahap praoperasional, anak telah menggunakan simbol dan bahasa untuk berkomunikasi. Perasaan dan intuitifnya sudah berkembang. Tahap praoperasional dibagi ke dalam dua tahap, yaitu preoperasional (2-4 tahun) dan tahap intuitif (4-8 tahun). Perbedaannya, pada tahap preoperasional anak telah mampu menggunakan bahasa tetapi secara sederhana, sedangkan pada tahap intuitif, anak telah memperoleh pengetahuan yang lebih abstrak. Pada tahap operasional konkret, kemampuan anak telah bertambah, yaitu anak sudah mulai menggunakan aturan-aturan yang jelas dan logis, dan ditandai adanya reversible dan kekekalan. Anak telah memiliki kecakapan berpikir logis, akan tetapi hanya dengan bendabenda yang bersifat konkret. Pada tahap operasional formal, anak sudah mampu berpikir abstrak dan logis dengan menggunakan pola berpikir kemungkinan-kemungkinan

(Suparno, 2001:158). Berdasarkan pembagian tahapan kognitif oleh Piaget, dapat dililah bahwa tahapan kognitif pada siswa sekolah dasar berada pada tahap raoperasional dan operasional konkret. Pada tahap ini anak telah mampu menggunakan bahasa dan pola pikirnya telah berkembang (Khadijah, 2016: 1928). Dengan demikian, pembelajaran yang mengarahkan pada pola pikir kritis telah mampu dilaksanakan pada tahapan ini.

\section{STRATEGI INTEGRATIF}

BERPIKIR

Pembelajaran integratif adalah pembelajaran yang mengkondisikan siswa pada suatu keadaan yang memungkinkan untuk mengembangkan konstruksi pengetahuan secara sistematis, sekaligus mengembangkan kemampuan berpikir kritis (Hunaepi, 2013: 65-73). Konstruksi pengetahuan sistematis adalah kombinasi antara fakta, generalisasi, konsep, dan hubungan antareleman pembangunnya. Dengan demikian, pembelajaran integratif tidak sekadar teoretis. Akan tetapi, pembelajaran yang memungkinkan siswa 
melakukan analisis terhadap datadata faktual. Pembelajaran integratif terdiri dari beberapa fase, yaitu fase berujung-terbuka, fase sebab-akibat, fase hipotesis, dan fase penerapan (Saputro dan Soeharto, 2015: 61-71).

Pembelajaran integratif akan sangat bermanfaat bagi siswa, seperti mengeksplorasi keberagaman, menggunakan berbagai bahan untuk meningkatkan efisiensi, mengembangkan diskusi, melatih berpikir kritis, dan meningkatkan kreativitas siswa (Abu Bakar dan Sharala, 2012: 54-61). Pembelajaran integratif tersebut telah mengakomodasi usaha untuk meningkatkan daya kritis siswa (Qodriyah, 2015: 177-189). Dengan kata lain, pembelajaran integratif merupakan seperangkat asumsi yang berisikan wawasan dan aktifitas berfikir dalam merencanakan pembelajaran dengan memadukan pengetahuan, pengalaman, dan keterampilan sebagai area pembelajaran.

Dalam pembelajaran integratif terdapat pola berpikit terarah (Zadina, 2014: 544-591). Berpikir terarah merupakan pola pikir yang telah diarahkan sebelumnya pada suatu titik yang bertujuan untuk memecahkan masalah. Dalam proses belajar-mengajar, berpikir terarah dapat dilihat dari strategi yang digunakan oleh guru. Dalam pembelajaran membaca misalnya, siswa diberi beberapa pertanyaan sebelum melakukan kegiatan membaca. Dengan demikian, siswa ketika membaca sudah terarah mencari jawaban berdasarkan pertanyaan yang telah disahikan sebelumnya (Iskandarwassid dan Dadang Sunendar, 2011). Pembelajaran integratif dan strategi berpikir terarah dapat digabungkan

30 | Jurnal Kredo Vol. 1 No. 2 April 2018 karena memiliki ruh yang sama, yaitu menitik beratkan pada daya nalar siswa (Suma, 2015). Dalam strategi berpikir terarah, tidak sekadar menentukan tujuan. Akan tetapi, membuat prediksi-prediksi yang mungkin terjadi (Hardini, 2012). Dengan demikian, konsep berpikir integratif yang dimaksud adalah berpikir dengan mendayagunakan data dan jaringannya, serta menitikkan pada tujuan tertentu.

\section{KARAKTERISTIK PEMBELAJARAN MEMBACA}

Pembelajaran membaca di sekolah dasar terbagi menjadi membaca permulaan dan membaca lanjut (Clarke, 2014: 47-58). Membaca permulaan merupakan pembelajaran yang menjadikan siswa mampu membaca. Dengan kata lain, membaca permulaan adalah membunyikan simbol-simbol bahasa (Kartika, 2004: 113-128). Dalam membaca permulaan terbagi ke dalam beberapa metode, seperti metode huruf, metode bunyi, metode global, dan metode sas. Membaca lanjut tidak lagi sekadar membunyikan simbol bahasa, tetapi membaca yang tujuannya mendapatkan informasi dari teks yang dibaca (Afandi, 2011: 85-98). Membaca lanjut memeiliki beberapa metode, di antaranya adalah membaca cepat, membaca skemming, membaca scanning, dan lain sebagainya. Strategi berpikir integratif merupakan strategi dalam pembelajaran membaca yang diterapkan dalam pembelajaran membaca lanjut. Akan tetapi, strategi berpikir integratif tidak sekadarmembaca untuk mendapatkan informasi, tetapi membaca untuk 
menumbuhkan daya pikir kritis pada siswa.

Pembelajaran membaca dapat diukur tingkat keberhasilannya melalui penilaian. Penilaian dalam pembelajaran membaca yang paing tepat adalah penilaian otentik (Abidin, 2012: 163-178). Penilaian otentik merupakan penilaian yang relevan dengan proses pembelajaran yang dilaksanakan (Nurgiyantoro, 2004: 91-115). Kegiatan membaca, maka yang dinilai adalah kemampuan siswa dalam membaca. Penilaian otentik merupakan penilaian proses. Dengan demikian, dalam penilaian ini yang dilihat tidak sekadar produk atau hasil dari pembelajaran.

\section{IMPLEMENTASI STRATEGI BERPIKIR INTEGRATIF DALAM PEMBELAJARAN MEMBACA}

Implementasi strategi berpikir integratif dapat dikelompokkan ke dalam beberapa tahap, yaitu pramembaca, kegiatan membaca, dan pascamembaca.

Pramembaca

1. Survei teks, mencari petunjuk tentang isi (judul, ilustrasi, subjudul)

Kegiatan survei jenis teks yang akan dibaca meliputi pengumpulan informasi terkait judul, ilustrasi yang digunakan, subjudul yang ada di dalam teks, dan penulis. Survei teks ini akan berfungsi sebagai pengenalan awal sehingga pembaca dapat menyiapkan pikiran dan menyesuaikan atmosfer bacaan.

2. Memberikan informasi tentang latar belakang teks

Guru memberikan informasi tentang latar belakang munculnya teks. Kejadian-kejadian yang menyebabkan teks itu muncul, kondisi politik dan ekonomi yang terjadi ketika teks itu diciptakan, dan budaya yang melingkupi teks. Hal ini akan membantu siswa dalam memahami konteks. Pemaknaan terhadap suatu bacaan tidak cukup sekadar tekstual, tetapi konteks situasi dan budaya akan sangat berpengaruh terhadap pemahaman teks.

3. Memberikan informasi kaitan teks dengan teks lain yang sejenis

Intertekstualitas diperlukan dalam memahami sebuah teks. Pada hakikatnya sebuah teks selalu berkaitan dengan teks lain. Hal ini akan membantu siswa dalam mengkonstruksi pemahaman teks.

4. Membuat prediksi tentang isi teks Setelah survei teks, memahami latar belakang munculnya teks, dan keterkaitan dengan teks lain, siswa diminta membuat prediksi tentang isi teks yang akan dibaca. Hal ini akan melatif siswa untuk berpikir komprehensif.

5. Menulis prediksi pada lembar prediksi

Prediksi yang telah dibuat oleh siswa kemudian ditulis dalam lembar prediksi. Lembar prediksi akan digunakan dalam aktifitas membaca dan pascamembaca.

6. Lembar prediksi berisi klasifikasi, seperti kolom terbukti-tidak terbukti, benar-salah, informasi tidak cukup, atau lainnya.

Lembar prediksi berbentuk kolom yang terdiri dari kolom terbuktitidak terbukti, benar-salah, informasi cukup-tidak cukup, dan keterangan lain. Kolom tersebut akan dicek list oleh siswa untuk melihat hasil prediksi dan isi teks. 
7. Menentukan tujuan membaca (apakah terbukti atau tidak prediksinya)

Langkah terakhir dalam kegiatan pramembaca adalah siswa menentukan apakah prediksi tentang isi teks terbukti atau tidak. Langkah ini akan terlihat prediksinya betul atau tidak setelah kegiatan pascamembaca dilakukan. Langkah ini akan melatih siswa dalam hal penalaran secara integratif.

Membaca

1. Membaca teks (diam/nyaring) secara utuh

Pada tahap ini siswa membaca seperti biasa. Kegiatan membaca dapat dilakukan dengan membaca dalam hati atau membaca nyaring. Siswa membaca teks secara utuh tanpa terganggu dengan kolom prediksi yang telah dibuat.

2. Menemukan informasi setiap paragraf/ teks secara utuh

Setelah siswa membaca teks, informasi secara utuh akan ditemukan. Siswa tidak diminta untuk fokus pada informasi di setiap paragraf, tetapi informasi keseluruhan.

3. Berdiskusi tentang informasi yang diperoleh dengan teman sejawat Informasi utuh yang telah diperoleh siswa selanjutnya didiskusikan dengan teman sejawat. Di dalam diskusi ini siswa akan berbagi pengetahuan dan mengkonstruksi pengetahuan baru.

4. Memberi tanda (X) pada klarifikasi di lembar prediksi dan menentukan berapa banyak kesesuaian hasil prediksi dengan isi bacaan

Tahap selanjutnya adalah siswa memberikan tanda di dalam kolom prediksi. Siswa mendata prediksi yang sesuai dengan isi bacaan.

Pascamembaca

1. Membanding isi prediksi dengan isi teks yang sebenarnya

Kegiatan pertama pada tahap pascamembaca adalah membandingkan relevansi isi prediksi dan isi teks. Siswa akan mengetahui isi teks yang benar setelah memlalui proses diskusi pada tahap membaca.

2. Menganalisis daftar prediksi dan menilai berapa banyak kesesuaian hasil prediksi dengan isi bacaan

Siswa melakukan analisis berapa besar prediksi terhadap isi teks tercapai. Semakin besar presentasi kebenarannya semakin baik penalaran integratif siswa.

3. Mengaitkan isi bacaan dengan pengalaman

Kegiatan penutup dari aktifitas membaca adalah siswa mengaitkan isi bacaan dengan pengalaman. Hal ini akan mereduksi pengalaman membaca lebih dalam di dalam ingatan siswa.

\section{PENUTUP}

Penalaran merupakan suatu proses berpikir yang menghubungkan data satu dengan data yang lain. Strategi berpikir integratif adalah strategi yang mengkondisikan siswa pada suatu keadaan yang memungkinkan untuk mengembangkan konstruksi pengetahuan secara sistematis, sekaligus mengembangkan kemampuan berpikir kritis. Dengan demikian, dalam strategi berpikir integratif menawarkan pengembangan penalaran siswa. Strategi berpikir integratif sangat 
relevan digunakan dalam karena strategi ini mengeksplore dan pembelajaran lintas kurikulum mengintegrasikan pengetahuan.

\section{DAFTAR PUSTAKA}

Abidin, Yunus. 2012. "Model Penilaian Otentik dalam Pembelajaran Membaca Pemahaman Beroreintasi Pendidikan Karakter. Jurnal Pendidikan Karakter, Tahun II, Nomor 2, Juni 2012: 163-178.

Abu Bakar, Siti Saniah dan Sharala Subramaniam. 2012. "Pengaruh Motivasi Instrumental dan Integratif dalam Pemilihan Strategi Pembelajaran Bahasa Melayu dalam Kalangan Penutur Asing. Jurnal Pendidikan Bahasa Melayu Vol. 2, Bil. 2 (Nov. 2012): 54-61.

Afandi, Rifki. 2011. "Integrasi Pendidikan Karakter dalam Pembelajaran IPS di Sekolah Dasar”. Pedagogia Vol. 1, No. 1, Desember 2011: 85-98.

Budiningsih, Asri. 2004. Belajar dan Pembelajaran. Yogyakarta: Rineka Cipta.

Bintz, William P. 2011. "Teaching Vocabulary Across the Curriculum.” (March): 44-54.

Bruce, Bertram C, and Judith Davidson. 1996. "An Inquiry Model for Literacy Across the Curriculum." 28: 281-300.

Chen, Pengfei, Andrew Kenneth, and Hsuanpo Wang. 2017. "Growing the Critical Thinking of Schoolchildren in Taiwan Using the Analects of Confucius." International Journal of Educational Research. http://dx.doi.org/10.1016/j.ijer.2017.02.002.

Clarke, P.J., Emma Truelove, Charles Hulme, and Margaret J.S. 2014. Developing Reading Comprehension. Westsussex: Wiley Blackwell.

Djoko, F. Warsito. Warsito. 2011. Logika. Jakarta: Indeks.

Hardini, Isriani. 2012. Strategi Pembelajaran Terpadu Teori Konsep Aplikasi. Yogyakarta: Familia.

Heafner, Tina L, George B Lipscomb, and Paul G Fitchett. 2014. "The Journal of Social Studies Research Instructional Practices of Elementary Social Studies Teachers in North and South Carolina." The Journal of Social Studies Research 38(1): 15-31. http://dx.doi.org/10.1016/j.jssr.2013.12.002.

Hunaepi, dkk. 2013. "Pengembangan Worksheet Tematik-Integratif pada Mata Pelajaran IPA Terpadu untuk Menumbuhkan Keterampilan Berpikir Kritis Siswa. Jurnal Lensa Kependidikan Fisika Vol. 1, No. 2: 65-73. 
Iskandarwassid dan Dadang Sunendar. 2011. Strategi Pembelajaran Bahasa. Bandung: Remaja Rosdakarya.

Kartika, Ester. 2004. "Memacu Minat Membaca Siswa Sekolah Dasar". Jurnal Pendidikan Penabur No. 03/ Th. III Tahun 2004: 113-128.

Khadijah. 2016. Pengembangan Kognitif Anak Usia Dini. Medan. Perdana Publishing.

Martin-beltrán, Melinda, Johanna M Tigert, Megan Madigan Peercy, and Rebecca D Silverman. 2017. "Using Digital Texts vs . Paper Texts to Read Together : Insights into Engagement and Mediation of Literacy Practices among Linguistically Diverse Students." International Journal of Educational Research 82: 135-46. http://dx.doi.org/10.1016/j.ijer.2017.01.009.

Nurgiyantoro, Burhan. 2004. "Penilaian Pembelajaran Sastra Berbasis Kompetensi". Diksi Vol. 11, No. 1 Tahun 2004: 91-115.

Plakans, Lia, and Atta Gebril. 2013. "Using Multiple Texts in an Integrated Writing Assessment: Source Text Use as a Predictor of Score." Journal of Second Language Writing 22(3): 217-30. http://dx.doi.org/10.1016/j.jslw.2013.02.003.

Qodriyah, Siti Hariyati dan Muhammad Nur Wangid. 2015. "Pengembangan SSP Tematik Integratif untuk Membangun Karakter Kejujuran dan Kepedulian Siswa SD Kelas II" Jurnal Prima Edukasia, Volume 3, Nomor 2, Juli 2015: $177-189$.

Ranjabar, Jacobus. 2014. Dasar-Dasar Logika Sebuah Langkah Awal untuk Masuk ke Berbagai Disiplin Ilmu dan Pengetahuan. Bandung: Alfabeta.

Rapar, Jan Hendrik. 1996. Pengantar Logika Asas-Asas Penalaran Sistematis. Yogyakarta: Kanisius

Renshaw, Peter. 2016. “(Re) Searching Learning across Contexts : Conceptual, Methodological and Empirical Explorations." : 8-10.

Saputro, Hengkang Bara dan Soeharto. 2015. "Pengembangan Media Komik Berbasis Pendidikan Karakter pada Pembelajaran Tematik-Integratif Kelas IV SD". Jurnal Prima Edukasia, Volume 3, Nomor 1, 2015: 61-71.

Suma, Muhammad Syarif. 2015. Strategi Pembelajaran Teori dan Praktik di Tingkat Pendidikan Dasar. Yogyakarta: Rajawali Press.

Suparno, Paul. 2001. Teori Perkembangan Kognitif Jean Piaget. Yogyakarta: Kanisius.

Weigle, Sara Cushing, and Keisha Parker. 2012. "Source Text Borrowing in an

34 | Jurnal Kredo

Vol. 1 No. 2 April 2018 
Integrated Reading / Writing Assessment." Journal of Second Language Writing 21(2): 118-33. http://dx.doi.org/10.1016/j.jslw.2012.03.004.

Yuan, Rui. 2017. "Appropriating National Curriculum Standards in Classroom Teaching: Experiences of Novice Language Teachers in China." International Journal of Educational Research 83: 55-64. http://dx.doi.org/10.1016/j.ijer.2017.02.011.

Zadina, Z.N, Rita Smilkstein, Deborah B.D, and Nancy M.A. 2014. College Reading The Science and Strategies of Expert Reader. Boston: Wadsworth. 